\title{
Determination of protein in goat milk by different analytical methods
}

\author{
Determinação de proteínas em leite de cabra por diferentes métodos analíticos \\ Juan Pablo Damián*, Inés Sacchi \\ Universidad de la República, Montevideo, Uruguai. *Author for correspondence: jpablodamian@gmail.com
}

Submission: 18/03/2019 / Acceptance: 06/03/2020

\begin{abstract}
The objective of this study was to correlate the Biuret, Lowry, Bradford, and Mlikoscan methods used to determine the level of protein in goat's milk and compare them with the Kjeldahl method. Milk samples collected from 18 goats of breeds Saanen $(n=5)$, Anglo-Nubian $(n=4)$, Pardo-alpina $(n=5)$, and Creole $(n=4)$ were analyzed. Correlation analyses between the different methods were performed using the Pearson test and the protein content between different breeds was compared using ANOVA. Total protein (TP) and casein (CN) concentrations obtained by all methods studied were positively correlated with the Kjeldahl method $(p<0.01)$. The Bradford method presented the lowest correlation coefficient. All methods apart from Bradford showed significant differences in TP and CN between the Anglo-Nubian and Pardoalpina breeds $(p<0.05)$. The Bradford method showed significant differences in TP between the Saanen and Pardo-alpina breeds $(p<0.05)$, and no differences were found between breeds reegarding $\mathrm{CN}$. In conclusion, the Bradford method had the lowest correlation value (TP and CN) with the Kjeldahl, and the Bradford method did not show the same pattern of differences between breeds in TP and CN, as was evidenced in all other methods. Therefore, the use of the Bradford method is not recommended to determine proteins in goat's milk.
\end{abstract}

KEYWORDS: Biuret, Bradford, Kjeldahl, Lowry, goats.

\section{RESUMO}

O objetivo deste estudo foi correlacionar os métodos de Biuret, Lowry, Bradford e Mlikoscan utilizados para a determinação da proteína do leite de cabra e compará-los com o método de Kjeldahl. Dezoito amostras de leite das raças Saanen $(n=5)$, Anglo-nubiana $(n=4)$, Pardo-alpina $(n=5)$ e crioula $(n=4)$ foram analisadas. Correlação entre os diferentes métodos foram realizadas (teste de Pearson) e o conteúdo de proteína entre diferentes raças foi comparado por ANOVA. As concentrações de proteína total (PT) e caseína (CN) foram correlacionadas positivamente entre todos os métodos com o Kjeldahl $(p<0,01)$, mostrando Bradford a menor correlação. Todos os métodos, exceto Bradford, mostraram diferenças significativas na PT entre as raças Anglo-nubiana e pardo-alpina $(p<0,05)$ e na $C N$ entre Saanen e Pardoalpina $(p<0,05)$. Bradford mostrou diferenças significativas em PT entre Saanen e Pardo-alpina $(p<0,05)$; e não foram encontradas diferenças entre raças na $\mathrm{CN}$. Em conclusão, o método de Bradford apresentou a menor correlação (TP e CN) com o Kjeldahl, e por Bradofrd não foi mostrado o mesmo padrão de diferenças entre raças em PT e CN, como foi evidenciado por todos os outros métodos. Portanto, sugerese que o método de Bradford não seja recomendado para a determinação de proteínas no leite de cabra.

PALAVRAS-CHAVE: Biureto, Bradford, Kjeldahl, Lowry, cabras.

The concentration of total protein (serum proteins and caseins) in milk is one of the parameters used to determine its quality, in addition to other indicators of composition and hygienic-sanitary quality (VEGA et al. 2007, FRAU et al. 2012). Milk proteins play an important role in technological products, such as the production of artisanal cheeses, which is of great importance in goat rearing. At the laboratory level, different methodologies have been developed to determine how the composition and especially the content of protein of milk and casein fractions influence technological processes, such as cheese performance (PELÁEZ PUERTO et al. 2003, DAMIÁN et al. 2008). However, different studies use different methods to determine the protein content in goat's milk (Biuret: RAIMONDO et al. 2013, Bradford: DOS SANTOS et al. 2017, Kjeldahl: OLALLA et al. 2009, Lowry: AL-ABDULKARIM et al. 2013, Milkoscan: EL-TARABANY et al. 2018); with the Kjeldahl method as a reference (BRADLEY et al. 1992, ZENG 1996). Although there are some 
studies that evaluated and correlated different methods to determine protein content in milk, they were made with human milk (KELLER \& NEVILLE 1986, LONNERDAL et al. 1987). Given that there is a high variability in the composition of milk in general and in the protein composition between species (POTOCNIK el al. 2011, BARLOWSKA et al. 2011), it is necessary to verify and validate the different methods according to the species. Considering this information, the objective of this study was to correlate different methods used in the determination of proteins in goat's milk (Lowry, Biuret, Bradford and Mlikoscan) and contrast them with the standard method of Kjeldahl. Additionally, the content of milk protein of different goat breeds was compared by the different methods to evaluate if all discriminate the same differences between breeds.

Individual milk samples from 18 goats of the breeds Saanen $(n=5)$, Anglo-Nubian ( $n=4)$, Pardo Alpina $(n=5)$, and Creole $(n=4)$ were collected. The goats were in the middle of lactation in a commercial farm in the Department of Canelones, Uruguay. All animals were subjected to the same care and sanitary and nutritional regime. Milk samples were preserved with $0.05 \%$ potassium dichromate, kept under refrigeration at $4{ }^{\circ} \mathrm{C}$. They were later skimmed (LD) by centrifugation at $2500 \mathrm{xg}$ for 30 minutes at $4{ }^{\circ} \mathrm{C}$. An aliquot of the LD of each animal was precipitated at $\mathrm{pH} 4.6$ for the determination of total casein (CT), calculated as the difference between total protein and serum protein $(C T=$ total protein in LD - total protein in serum). The content of total nitrogen (NT), soluble nitrogen at $\mathrm{pH} 4.6$ (NS), and casein nitrogen (NC) (calculated as NC = NT - NS) was analyzed by the Kjeldahl method ( $\mathrm{N} \times 6.38)$ (AOAC 1991).

The Lowry (Folin-Ciocalteu, LOWRY et al. 1951), Biuret (reaction of cupric ion in alkaline solution, GORNALL et al. 1949), Bradford (Bio-Rad - micro, Brilliant Blue G-250, BRADFORD 1976), and Milkoscan (Milk Scan-104 instrument, Foss Electric, Hillerod, Denmark) methods were employed to determine the concentration of protein in the milk.

The correlation analyzes between the different methods and the Kjeldahl method was performed using the Pearson correlation test. The comparison of the total protein content between the different breeds for each method was analyzed by ANOVA. Differences were considered significant when $p<0.05$. The data are presented as mean \pm standard deviation (SD).

The concentration of total proteins in LD was positively and significantly $(p<0.01)$ correlated with Milkoscan, Lowry, Biuret, and Bradford regarding the Kjeldahl method, with correlation coefficients ( $r$ ) of $0.97,0.93,0.88$, and 0.76 , respectively. Regarding the casein, the correlations with the Kjeldahl method were also significant $(p<0.01)$, with $r$ of $0.85,0.77$, and 0.60 for the Lowry, Biuret, and Bradford methods, respectively. The Lowry and Biuret methods had the highest correlation coefficients with Kjeldahl unlike the Bradford method. These results agree with other studies done with human milk and with previously skim samples (KELLER \& NEVILLE 1986). However, different results were reported by LONNERDAL et al. (1987), who reported that the Bradford method, among others, achieved the highest correlation coefficient with the Kjeldahl method. A possible explanation for the differences in the results is that LONNERDAL et al. (1987) worked with whole milk, unlike our work and those of KELLER \& NEVILLE (1986) in which the milk was skimmed. The content of fat may have possibly affected the content of protein in milk using the different methods.

For the Kjeldahl, Lowry, Biuret, and Milkoscan methods, significant differences $(p<0.05)$ were found in the total protein content in the LD between the Anglo-Nubian and Pardo Alpina breeds (Figure 1A). However, this difference did not occur when using the Bradford method, by which a significant difference $(p<0.05)$ was found between the Saanen and Pardo Alpina breeds (Figure 1A). Similar results were found for the casein content, in which the Kjeldahl, Lowry, and Biuret methods showed significant differences $(p<0.05)$ between Anglo Nubian and Pardo Alpina breeds, whereas by the Bradford method no differences were found between breeds (Figure 1B).

The differences in the total protein content of LD and casein per breed had the same pattern when determined using the Kjeldahl, Lowry, and Biuret methods. This is important since there was a high and significant correlation when using these methods and the different methods achieved the same differences between breeds. However, the Bradford method not only has the lowest values of protein correlation coefficients with Kjeldahl, but it was also the only method by which the difference in protein content between breeds dis not correspond to that obtained by the others methods.

In conclusion, the Lowry and Biuret methods (both for total proteins and caseins) as well as the Milkoscan method (only for total proteins), present a high correlation with the Kjeldahl method. Furthermore, all these methods obtained the same pattern of differences between breeds in the milk protein content. \begin{tabular}{ll}
\hline Rev. Ciênc. Agrovet., Lages, SC, Brasil (ISSN 2238-1171) & 246
\end{tabular} 
However, the Bradford did not show the same pattern as the other methods, and since it had the lowest correlation value with the Kjeldahl, it is not recommended for the determination of proteins in goat's milk.

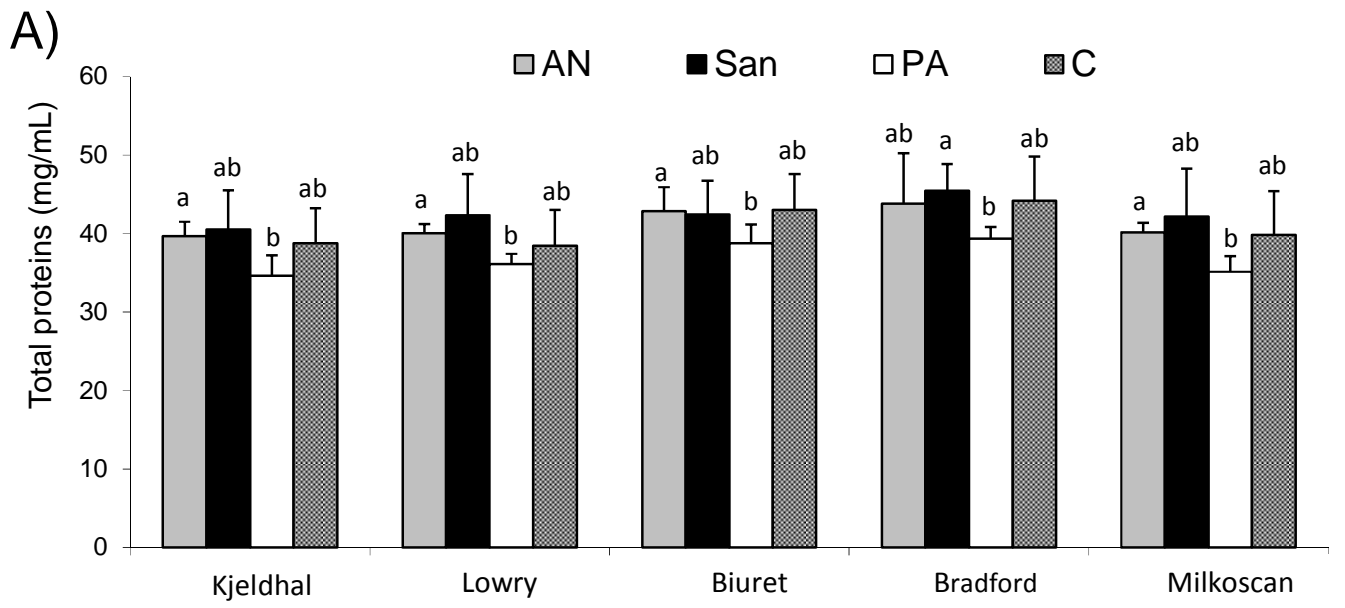

B)

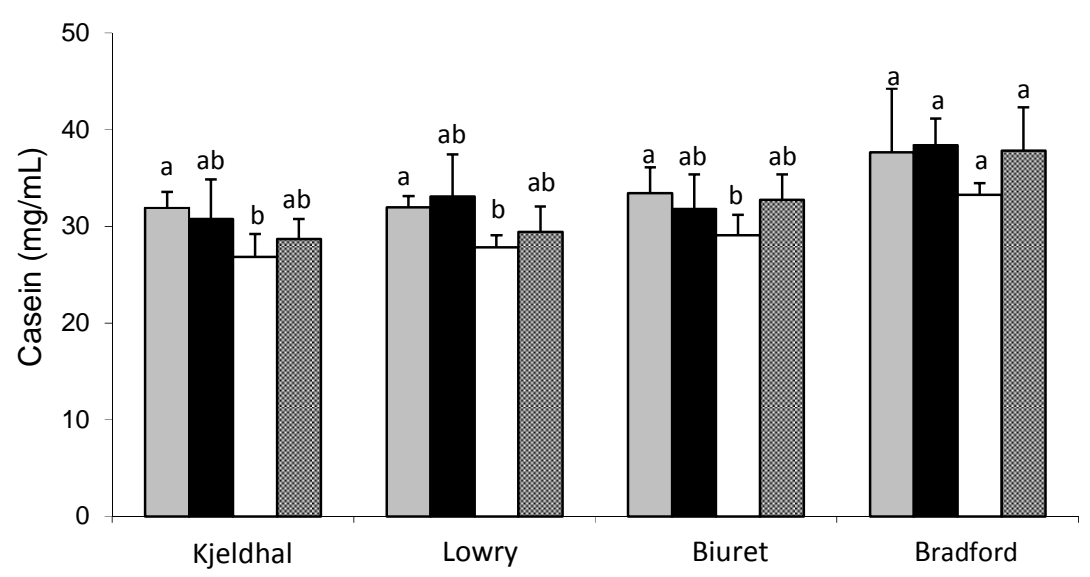

Figure 1. Total protein (A) and casein (B) content in skimmed milk by the Kjeldahl, Lowry, Biuret, Bradford, and Milkoscan methods in the Anglo-Nubian (AN), Saanen (San), Pardo Alpina (PA), and Creole (C) breeds. Different letters between breeds for the same method differ with $p<0.05$.

\section{ACKNOWLEDGEMENTS}

We thank Stella Reginensi and Delma De Lima for their help and for providing us with the conditions for conducting this work.

\section{REFERENCES}

Al-ABDULKARIM BO et al. 2013. Determination of chemical composition, and storage on dried fermented goat milk product. Journal of the Saudi Society of Agricultural Sciences 12: 161-166.

BARLOWSKA J et al. 2011. Nutritional value and Technological suitability of milk from various animal species used for Dairy Production. Comprehensive Reviews in Food Science and Food Safety 10: 291-302.

BRADFORD M 1976. A rapid and sensitive method for the quantitation of microgram quantities of protein utilizing the principle of protein-dye binding. Analytical Biochemist 72: 248-254.

BRADLEY RL et al. 1992. Chemical and physical methods. In: MARSHALL RT. (Ed.) Standard Methods for the Examination of Dairy Products. Washington DC: American Public Health Association. p.433-531.

DAMIÁN JP et al. 2008. Cheese yield, casein fractions and major components of milk of Saanen and Anglo-Nubian dairy goats. Arquivo Brasileiro de Medicina Veterinária e Zootecnia 60: 1564-1569.

DOS SANTOS ASO et al. 2017. Major goat milk protein: separation and characterization by "Lab-On-A-Chip" microfluidic electrophoresis. Boletim Centro de Pesquisa de Processamento de Alimentos 35: 1-13.

EL-TARABANY MS et al. 2018. Characterization of progesterone profile, physiological responses, milk composition and 
blood biochemical and hematological indices at the early stage of lactation in goats. Biological Rhythm Research 50 : 647-657.

FRAU F et al. 2012. Composición físico-química y calidad microbiológica de leche de cabra en rebaño bajo sistema extensivo en Santiago del Estero (Argentina). Revista de la Facultad de Agronomía, La Plata 111: 1-7.

GORNALL AG et al. 1949. Determination of serum proteins by means of the biuret reaction. Journal of Biological Chemistry 177: 751-766.

KELLER RP \& NEVILLE MC 1986. Determination of Total Protein in Human Milk: Comparison of Methods. Clinical Chemistry 32: 120-123.

LONNERDAL BO et al. 1987. Compartmentalization and Quantitation of protein in human milk. The Journal of Nutrition 117: $1385-1395$.

LOWRY OH et al. 1951. Protein measurement with the folin phenol reagent. Biology Chemistry 193: 265-275.

AOAC. 1991. Association of Official Analytical Chemists. Official methods of analysis, 15.ed. Washington, DC: AOAC.

OLALLA M et al. 2009. Nitrogen fractions of Andalusian goat milk compared to similar types of commercial milk. Food Chemistry 113: 835-838.

PELÁEZ PUERTO P et al. 2003. Caracterización físico-química de quesos frescos elaborados con leche de cabra en la isla de Tenerife, CYTA. Journal of Food 4: 103-108.

POTOCNIK K et al. 2011. Mare's milk: composition and protein fraction in comparison with different milk species. Portal Znanstvenih Casopisa Republike Hrvatske 61: 107-113.

RAIMONDO RFS et al. 2013. Dynamic in the concentration of whey proteins in the mammary secretion of goats during the dry period. Small Ruminant Research 113: 239-246.

VEGA S et al. 2007. Características físicas y químicas de leche de cabra de razas Alpino Francesa y Saanen en épocas de lluvia y seca. Revista Salud Animal 29: 160-166.

ZENG SS 1996. Comparison of goat milk standards with cow milk standards for analyses of somatic cell count, fat and protein in goat milk. Small Ruminant Research 21: 221-225. 